\title{
Peningkatan Hasil Belajar Siswa Menggunakan Metode Problem Solving dalam Pembelajaran IPA
}

\author{
Ketut Sutarmi ${ }^{*}$, I Md Suarjana² \\ 1Universitas Pendidikan Ganesha \\ ${ }^{2}$ Universitas Pendidikan Ganesha
}

\begin{abstract}
Abstrak
Penelitian ini bertujuan untuk meningkatkan hasil belajar siswa melalui metode Problem Solving pada mata pelajaran IPA di kelas VA SD No. 2 Dalung Tahun Pelajaran 2016/2017. Jenis ini adalah Penelitian tindakan kelas. Penelitian ini dilaksanakan dalam 2 siklus dan empat kali pertemuan setiap siklusnya. Subjek penelitian ini adalah siswa kelas V A di SD No. 2 Dalung yang berjumlah 33 siswa. Data dianalisis dengan tehnik statistik deskriptif kuantitatif. Hasil penelitian menunjukkan bahwa terjadi peningkatan persentase hasil belajar siswa kelas VA SD No. 2 Dalung. Presentase rata-rata hasil belajar siswa pada siklus I sebesar 72,12\%. Presentase ratarata hasil belajar pada siklus II sebesar $82,58 \%$. Hasil penelitian ini menunjukkan bahwa penerapan metode Problem Solving pada mata pelajaran IPA dapat meningkatkan hasil belajar siswa kelas V A SD No. 2 Dalung Tahun Pelajaran $2016 / 2017$.
\end{abstract}

Keywords:

Hasil Belajar, Problem

Solving, IPA

\section{Pendahuluan}

Indonesia sebagai salah satu negara berkembang sampai saat ini telah mencapai banyak kemajuan dalam berbagai bidang melalui tahapan-tahapan pembangunan. Pemerintah dan bangsa Indonesia telah berjuang untuk mencapai tujuan pembangunan yaitu masyarakat adil dan makmur material dan spiritual. Pendidikan di Indonesia khususnya pada jenjang Sekolah Dasar (SD) merupakan hal yang penting karena pendidikan di SD merupakan pendidikan yang paling mendasar dan merupakan landasan bagi pendidikan selanjutnya. Untuk itu setiap pembelajaran yang diberikan di SD perlu diarahkan kepada pembentukan fondasi yang kokoh yaitu terbentuknya konsep dasar yang kuat pada diri siswa sehingga siswa siap untuk mempelajari materi selanjutnya. Ilmu Pengetahuan Alam (IPA) termasuk mata pelajaran yang dapat meningkatkan kemampuan kritis siswa dalam menyikapi fenomena alam yang terjadi dalam kehidupan.

Pembelajaran IPA yang berkembang saat ini khususnya di Sekolah Dasar menuntut siswa agar menemukan masalah serta memecahkannya (Sudana, dkk., 2017). Widiana (2016) Dalam pembelajaran IPA guru dituntut untuk mengajak siswa memanfaatkan alam sebagai sumber belajar. IPA memberikan banyak manfaat bagi siswa, diantaranya siswa dapat mengenal lingkungan sekitar, mendapatkan pengalaman langsung dengan melakukan berbagai percobaan yang terkait dengan lingkungan hidup. IPA adalah ilmu pengetahuan yang mempelajari objek-objek alam semesta beserta isinya. Dalam pembelajaran IPA siswa harus diberikan kesempatan untuk mengalami dan menemukan sendiri tentang makna dari materi yang diajarkan dengan berpikir kritis sehingga mudah dipahami siswa dalam mata pelajaran IPA. Oleh karena itu, pembelajaran IPA di Sekolah Dasar menekankan pada pemberian pengalaman belajar secara langsung. Pengembangan keterampilan proses sangat menunjang dalam menggali pengetahuan siswa dari alam bebas. Dari keterampilan proses ini dapat dikembangkan sikap ilmiah.

Kondisi saat ini, khususnya dalam proses pembelajaran IPA dianggap sulit oleh para siswa di sekolah, mulai dari tingkat Sekolah Dasar sampai Perguruan Tinggi. Permasalahan pengajaran IPA yang masih menggunakan metode ceramah sering kali kurang diminati, membosankan dan cenderung dianggap sulit oleh siswa. Hal tersebut dapat berpengaruh terhadap rendahnya hasil belajar IPA siswa. Kondisi seperti ini penulis temukan pada kegiatan pembelajaran IPA di SD No. 2 Dalung. Berdasarkan dari pengamatan yang penulis lakukan di SD No. 2 Dalung pada saat mengajarkan IPA Kelas VA pada Tanggal 2 Agustus 2016 menggunakan metode ceramah. Dari data yang ada terlihat perolehan nilai IPA siswa masih

* Corresponding author.

E-mail Addresses: ketut_sutarmi@yahoo.com(Ketut Sutarmi) suarjana_pgsd@yahoo.co.id(I Md Suarjana) 
jauh dari memuaskan. Masih banyak siswa kelas VA di SD No. 2 Dalung yang belum mampu mencapai nilai yang memuaskan. Saat dilakukan test pra siklus data terlampir, diperoleh hasil belajar rata-rata kelas baru mencapai 64,09\% yang berarti hasil belajar siswa kelas VA tergolong "rendah".

Melihat kenyataan ini, salah satu upaya yang dapat dilakukan untuk meningkatkan hasil belajar siswa dengan mengoptimalkan aktivitas pembelajaran, membuat alat peraga murah dan mendesain skenario pembelajaran yang dapat meningkatkan keaktifan siswa dalam belajar, misalnya dengan menerapkan pendekatan belajar aktif. Salah satu pembelajaran yang bisa digunakan untuk menyelesaikan persoalan itu adalah dengan menerapkan pendekatan pemecahan masalah (Problem Solving). Metode pemecahan masalah merupakan cara memberikan pengertian dengan menstimulasi anak didik untuk memperhatikan, menelaah dan berpikir tentang suatu masalah untuk selanjutnya menganalisis masalah tersebut sebagai upaya untuk memecahkan masalah. Syaiful Bahri dan Aswan Zain (2006) menjelaskan bahwa metode problem solving (metode pemecahan masalah) bukan hanya sekedar metode mengajar, tetapi juga merupakan suatu metode berpikir, sebab dalam problem solving dapat menggunakan metodemetode lainnya yang dimulai dengan mencari data sampai kepada menarik kesimpulan.

Ada beberapa alasan mengapa pendekatan Problem Solving di anggap cocok untuk menyelesaikan masalah pembelajaran yang ditemukan ini, diantaranya: Melatih cara berpikir dan bernalar dalam menarik kesimpulan, misalnya melalui kegiatan eksplorasi, eks perimen, menunjukkan kesamaan, perbedaan, konsisten dan inkonsisten, Mengembangkan kemampuan memecahkan masalah, Meng embangkan kemampuan menyampaikan informasi atau menkomunikasikan gagasan antara lain melalui pembicaraan lisan, catatan, grafik, peta diagram dalam men jelaskan gagasan.Dengan pemecahan masalah atau Problem Solving diharapkan pem ebelajaran akan lebih bermakna, menarik dan memacu kreativitas bagi siswa karena pendekatan pemecahan masalah atau Problem Solving dapat dikatakan sebagai muara dalam pembelajaran IPA, sebab berbagai aspek kognitif, afektif, dan psikomotor terlibat didalamnya. Di pihak lain kita dituntut untuk menerima permasalahan sebagai suatu tatangan yang harus dicarikan solusinya, dan akhirnya harus mempunyai kemampuan untuk melaksanakan pemecahan masalah dalam bentuk perbuatan nyata. Sesuai dengan pengertian IPA, bahwa IPA merupakan pengetahuan manusia tentang gejala-gejala alam dan kebendaan yang diperoleh dengan cara obrservasi, eksperimen atau penelitian atau uji coba yang berdasarkan pada hasil pengamatan manusia. Pengamatan manusia dapat berupa fakta-fakta, aturan-aturan, hukum-hukum, prinsip-prinsip, teori-teori dan lain sebagainya. Maka untuk mencari solusi bagi permasalahan perlu diadakan uji coba secara langsung.

Problem solving melatih siswa terlatih mencari informasi dan mengecek silang validitas informasi itu dengan sumber lainnya, juga problem solving melatih siswa berfikir kritis dan metode ini melatih siswa memecahkan dilema (Kartawidjaya, 1988; Firli, dkk, 2017; Widiana, 2016). Sehingga dengan menerapkan metode problem solving ini siswa menjadi lebih dapat mengerti bagaimana cara memecahkan masalah yang akan dihadapi pada kehidupan nyata di luar lingkungan sekolah. Untuk mendukung strategi belajar mengajar dengan menggunakan metode problem solving ini, guru perlu memilih bahan pelajaran yang memiliki permasalahan. Materi pelajaran tidak terbatas hanya pada buku teks di sekolah, tetapi juga di ambil dari sumber-sumber lingkungan seperti peristiwa-peristiwa kemas yarakatan atau peristiwa dalam lingkungan sekolah (Gulo, 2002). Tujuannya agar memudahkan siswa dalam menghadapi dan memecahkan masalah yang terjadi di lingkungan sebenarnya dan siswa memperoleh pengalaman tentang penyelesaian masalah sehingga dapat diterapkan di kehidupan nyata. Kebaikan atau keuntungan dalam penerapan metode problem solving: 1) Mendidik murid untuk berfikir secara sistematis. 2) Mendidik berfikir untuk mencari sebab-akibat. 3) Menjadi terbuka untuk berbagai pendapat dan mampu membuat pertimbangan untuk memilih satu ketetapan. 4) Mampu mencari berbagai cara jalan keluar dari suatu kesulitan atau masalah. 5) Tidak lekas putus asa jika menghadapi suatu masalah. 6) Belajar bertindak atas dasar suatu rencana yang matang. 7) Belajar bertanggung jawab atas keputusan yang telah ditetapkan dalam memecahkan suatu masalah. 8) Tidak merasa hanya bergantung pada pendapat guru saja. 9) Belajar menganalisa suatu persoalan dari berbagai segi. 10) Mendidik suatu sikap-hidup, bahwa setiap kesulitan ada jalan pemecahannya jika dihadapi dengan sungguh-sungguh.

Menurut Bahri (2010) Metode adalah suatu cara yang diperlukan untuk mencapai tujuan yang telah ditetapkan. Sedangkan menurut Yamin (2013) metode pembelajaran merupakan bagian dari strategi instruksional, metode instruksional berfungsi sebagai cara untuk menyajikan, menguraikan, memberi contoh, dan memberi latihan kepada peserta didik untuk mencapai tujuan tertentu, tetapi tidak setiap metode instruksional sesuai digunakan untuk mencapai tujuan instruksional tertentu. Menurut Sanjaya (2011) ada beberapa pertimbangan yang harus diperhatikan dalam memilih dam menentukan metode pengajaran, yaitu: (1) pertimbangan yang berhubungan dengan tujuan yang ingin dicapai, (2) pertimbangan yang berhubungan dengan bahan atau materi pembelajaran, (3) pertimbangan dari sudut siswa, (4) pertimbangan dari nilai efektivitas dan efisiensi. Tan (dalam Rusman 2011) mengemukakan metode berbasis masalah merupakan inovasi dalam pembelajaran karena kemampuan berpikir siswa 
betul-betul dioptimalisasikan melalui proses kerja kelompok atau tim yang sistematis, sehingga siswa dapat memberdayakan, mengasah, menguji, dan mengembangkan kemampuan berpikirnya secara berkesinambungan.

Menurut Bahri (2010) pada proses pembelajaran berbasis masalah para peserta didik belajar merumuskan memecahkan masalah, memberikan respons terhadap rangsangan yang menggambarkan atau membangkitkan situasi problematik, yang mempergunakan berbagai kaidah yang telah dikuasainya. Metode pembelajaran problem solving bukan hanya sekedar metode mengajar tetapi juga merupakan suatu metode berpikir sebab dalam problem solving kegiatan belajar mengajar dimulai dengan mencari data sampai pada menarik kesimpulan (Dharma, 2008). Metode ini menitikberatkan pada aktivitas siswa dalam prosesbelajar mengajar, guru berperan memberikan pengawasan serta bimbingan kepada siswa, sehingga kesulitan dalam memecahkan masalah dapat dipecahkan secara benar dan jelas.

Metode problem solving memiliki beberapa keunggulan, diantaranya (Sanjaya, 2011): (1) merupakan teknik yang cukup bagus untuk lebih memahami isi pelajaran, (2) dapat menantang kemampuan siswa serta memberikan kepuasan untuk menemukan pengetahuan baru bagi siswa, (3) dapat meningkatkan aktivitas pembelajaran siswa, (4) dapat membantu siswa bagaimana mentransfer pengetahuan mereka untuk memahami masalah dalam kehidupan nyata, (5) dapat membantu siswa untuk mengembangkan pengetahuan barunya dan bertanggung jawab dalam pembelajaran yang mereka lakukan serta dapat mendorong untuk melalukan evaluasi sendiri baik terhadap hasil maupun proses belajarnya, (6) bisa memperlihatkan kepada siswa bahwa setiap mata pelajaran (matematika, IPA, sejarah dan lain sebagainya), pada dasarnya merupakanmcara berpikir, dan sesuatu yang harus dimengerti oleh siswa, bukan hanya sekedar belajar dari guru atau dari buku-buku saja, (7) dianggap lebih menyenangkan dan disukai siswa, (8) dapat mengembangkan kemampuan siswa untuk berpikir kritis dan mengembangkan kemampuan mereka untuk menyesuaikan dengan pengetahuan baru, (9) dapat memberikan kesempatan pada siswa untuk mengaplikasikan pengetahuan yang mereka miliki dalam dunia nyata, dan (10) dapat mengembangkan minat siswa untuk secara terus-menerus belajar sekalipun belajar pada pendiidkan formal telah berakhir.

Menurut Widiana (2016), pembelajaran IPA harus melibatkan keaktifan anak secara penuh (active learning) dengan cara guru dapat merealisasikan pembelajaran yang mampu memberi kesempatan pada anak didik untuk melakukan keterampilan proses meliputi: mencari, menemukan, menyimpulkan, mengkomunikasikan sendiriberbagai pengetahuan, nilai-nilai, dan pengalaman yang dibutuhkan. IPA atau sains secara pragmatis dapat ditinjaumenurut fungsi-fungsinya. Fungsi pokok yang dikumpulkan dari pendapat para pelaku, pengguna dan pemirsa sains menurut (Suryani, 2010) yaitu: a) Sains membantu manusia berpikir dalam pola sistematis. b) Sains dapat menjelaskan gejala alam serta hubungan satu sama lain. c) Sains dapat digunakan untuk meramalkan gejala alam yang akan terjadi berdasarkan pola gejala alam yang dipelajari. d) Sains digunakan untuk menguasai alam dan mengendalikannya demi kepentingan manusia. e) Sains digunakan untuk melestarikan alam karena sumbangan ilmunya mengenai alam. Pembelajaran IPA sebaiknya dilaksanakan secara inkuiri ilmiah (scientific inquiry) untuk menumbuhkan kemampuan berpikir, bekerja dan bersikap ilmiah serta mengkomunikasikannya sebagai aspek penting kecakapan hidup. Oleh karena itu pembelajaran IPA di SD/MI menekankan pada pemberian pengalaman belajar secara langsung melalui penggunaan dan pengembangan keterampilan proses dan sikap ilmiah (Theresia, 2010).

Untuk mendukung proses pembelajaran ini menjadi lebih menyenagkan dan menantang, pembelajaran dengan problem solving dibagi menjadi beberapa siklus seperti yang disampaikan oleh Bransford Strain, Hayes, Strenberg yang dikutip oleh (Janet. E Davinson dan Robert J.S, 2003). Siklus tersebut terdiri dari beberapa tahap yang mana pemecahan masalah tersebut harus mengikuti langkah sebagai berikut: (1) Identifikasi masalah; (2) Menjelaskan dan menggambarkan masalah tersebut; (3) Mengembangkan strategi pemecahan; (4) Mengorganisasi pengetahuan mereka tentang masalah tersebut; (4) Mempersiapkan fisik dan mental untuk memecahkan masalah; (6) Mengawasi kemajuan mereka dalam menuju tujuan; (7) Mengevaluasi solusi mereka apakah sudah sesuai dengan pemecahan masalah tersebut. Menurut (Conny R. Semiawan, 2009), bahwa Siklus problem solving melalui lima langkah yaitu identifikasi masalah, memperoleh sumber untuk pengatasan masalah, melengkapi strategi pengatasan masalah, monitoring, dan evaluasi terhadap pengatasan masalah. Pendapat senada juga dinyatakan oleh (Utomo Danajaya, 2010) menjelaskan Problem solving dilakukan dengan proses : (1) Identifikasi Masalah; (2) Merumuskan Masalah; (3) Melaksanakan eksperimen/percobaan; (4) Memonitor perkembangan; (5) Mencatat keberhasilan dan kegagalan; (6) Memperbaiki kegagalan atau mengembangkan keberhasilan sehingga dicapai tujuan.

Pengertian Problem Solving adalah Metode problem solving atau sering juga disebut dengan nama Metode Pemecahan Masalah merupakan suatu cara mengajar yang merangsang seseorang untuk menganalisa dan melakukan sintesa dalam kesatuan struktur atau situasi di mana masalah itu berada, 
atas inisiatif sendiri. Metode ini menuntut kemampuan untuk dapat melihat sebab akibat atau relasi-relasi diantara berbagai data, sehingga pada akhirnya dapat menemukan kunci pembuka masalahnya. Kegiatan semacam ini merupakan ciri yang khas daripada suatu kegiatan intelegensi (Angga Wiguna, dkk., 2016).

Metode ini mengembangkan kemampuan berfikir yang dipupuk dengan adanya kesempatan untuk mengobservasi problema, meng umpulkan data, menganalisa data, menyusun suatu hipotesa, mencari hubungan (data) yang hilang dari data yang telah terkumpul untuk kemudian menarik kesimpulan yang merupakan hasil pemecahan masalah tersebut. Cara berfikir semacam itu lazim disebut cara berfikir ilmiah. Cara berfikir yang menghasilkan suatu kesimpulan atau keputusan yang diyakini kebenarannya karena seluruh proses pemecahan masalah itu telah diikuti dan dikontrol dari data yang pertama yang berhasil dikumpulkan dan dianalisa sampai kepada kesimpulan yang ditarik atau ditetapkan. Cara berfikir semacam itu benar- benar dapat dikembangkan dengan menggunakan Metode Pemecahan Masalah (Jusuf Djajadisastra, 1982; Nurliawaty, 2017).

Metode problem solving (metode pemecahan masalah) bukan hanya sekedar metode mengajar tetapi juga merupakan suatu metode berpikir, sebab dalam problem solving dapat menggunakan metodemetode lainnya dimulai dengan mencari data sampai kepada menarik kesimpulan. Langkah-langkah metode ini antara lain: 1) Adanya masalah yang jelas untuk dipecahkan. Masalah ini harus tumbuh dari siswa sesuai dengan taraf kemampuannya. 2) Mencari data atau keterangan yang dapat digunakan untuk memecahkan masalah tersebut. Misalnya, dengan jalan membaca buku- buku, meneliti, bertanya, berdiskusi, dan lain- lain. 3) Menetapkan jawaban sementara dari masalah tersebut. Dugaan jawaban ini tentu saja didasarkan kepada data yang telah diperoleh, pada langkah kedua diatas. 4) Menguji kebenaran jawaban sementara tersebut. Dalam langkah ini siswa harus berusaha memecahkan masalah sehingga betul-betul yakin bahwa jawaban tersebut betul-betul cocok. Apakah sesuai dengan jawaban sementara atau sama sekali tidak sesuai. Untuk menguji kebenaran jawaban ini tentu saja diperlukan metode-metode lainnya seperti, demonstrasi, tugas diskusi, dan lain-lain. 5) Menarik kesimpulan. Artinya siswa harus sampai kepada kesimpulan terakhir tentang jawaban dari masalah yang ada (Nana Sudjana, 1989).

Penyelesaian masalah dalam metode problem solving ini dilakukan melalui kelompok. Suatu isu yang berkaitan dengan pokok bahasan dalam pelajaran diberikan kepada siswa untuk diselesaikan secara kelompok. Masalah yang dipilih hendaknya mempunyai sifat conflict issue atau kontroversial, masalahnya dianggap penting (important), urgen dan dapat diselesaikan (solutionable) oleh siswa (Gulo, 2002).

Tujuan utama dari penggunaan metode Pemecahan Masalah adalah: 1) Mengembangkan kemampuan berfikir, terutama didalam mencari sebab-akibat dan tujuan suatu masalah. Metode ini melatih murid dalam cara-cara mendekati dan cara-cara mengambil langkah-langkah apabila akan memecahkan suatu masalah. 2) Memberikan kepada murid pengetahuan dan kecakapan praktis yang bernilai/bermanfaat bagi keperluan hidup sehari-hari. Metode ini memberikan dasar-dasar pengalaman yang praktis mengenai bagaimana cara-cara memecahkan masalah dan kecakapan ini dapat diterapkan bagi keperluan menghadapi masalah-masalah lainnya didalam masyarakat. 3) Suatu masalah dapat dikatakan masalah yang baik bila memenuhi syarat-syarat sebagai berikut: a) Jelas, dalam arti bersih dari pada kesalahan-kesalahan bahasa maupun isi pengertian yang berbeda. Istilah yang dipergunakan tidak memiliki dua pengertian yang dapat ditafsirkan berbeda-beda. b) Kesulitannya dapat diatasi. Maksudnya ialah bahwa pokok persoalan yang akan dipecahkan tidak merupakan pokok berganda/kompleks. c) Bernilai bagi murid. Hasil ataupun proses yang diamati murid harus bermanfaat dan menguntungkan pengalaman murid atau memperkaya pengalaman murid. d) Sesuai dengan taraf perkembangan psikologi murid. Masalah yang dipecahkan tidak terlalu mudah tetapi juga tidak terlalu sulit. Jadi harus sesuai dengan kapasitas pola pikir murid. e) Praktis, dalam arti mungkin dijumpai dalam kehidupan sehari-hari. Atau, problema itu diambil dari praktek kehidupan sehari-hari, dari lingkungan sekitar dimana murid itu berada (Jusuf Djajadisastra, 1982).

\section{Metode}

Penelitian ini dilaksanakan di SD No. 2 Dalung tahun pelajaran 2016/2017. Jenis penelitian yang dilaksanakan adalah penelitian tindakan kelas (PTK) (Wardhani, 2007; Kasihani, 2006). PTK ini dilakukan dengan kerjasama dengan guru sebagai wali kelas melalui refleksi diri untuk memperbaiki kinerjanya sehingga hasil belajar siswa bisa ditingkatkan. Subjek penelitian ini adalah siswa kelas V A di SD No. 2 Dalung yang berjumlah 33 siswa. Penelitian ini dilaksanakan dalam 2 siklus, dimana tiap siklus dilaksanakan dalam 3 kali pertemuan yaitu 2 kali pertemuan untuk pembelajaran dan 1 kali pertemuan untuk tes hasil belajar IPA. Data yang dikumpulkan dalam penelitian ini, yaitu data tentang hasil belajar siswa terhadap pembelajaran yang diterapkan. Data hasil belajar siswa ini didapat dari tes hasil belajar yang dilaksanakan pada akhir siklus. Data yang telah dikumpulkan dianalisis sesuai dengan teknik statistik deskriptif kuantitatif. Selanjutnya data hasil analisis akan dikonversikan ke dalam PAP skala lima 
seperti pada Tabel 1. Penelitian ini dikatakan berhasil apabila rata-rata kelas yang diperoleh telah mencapai Indikator keberhasilan dalam penelitian ini yaitu berada pada rentang 80\% - 89\% dengan kriteria tinggi.

Tabel 1 Kriteria Penilaian Acuan Patokan (PAP)

\begin{tabular}{ll}
\hline Prosentase $(\%)$ & Tingkat Hasil Belajar \\
\hline $90-100$ & Sangat Tinggi \\
$80-89$ & Tinggi \\
$65-79$ & Sedang \\
$55-64$ & Rendah \\
$0-54$ & Sangat Rendah \\
\hline
\end{tabular}

\section{Hasil dan pembahasan}

Berdasarkan hasil pengumpulan data hasil belajar dan analisis yang dilakukan pada siklus I maka secara klasikal penelitian pada siklus I belum berhasil karena belum memenuhi kriteria keberhasilan penelitian yaitu penelitian dikatakan berhasil bila nilai rata-rata kelas minimal 80. Sedangkan nilai ratarata kelas yang diperoleh baru mencapai 72,12. Berdasarkan kriteria di atas maka persentase rata-rata hasil belajar siswa pada mata pelajaran IPA pada siklus I sebesar $72,12 \%$ berada pada rentang $65 \%-79 \%$ dengan kriteria sedang.

Rendahnya hasil belajar yang diharapkan pada siklus I disebabkan oleh beberapa kendala yaitu: (1) siswa belum mampu membuat pertanyaan sendiri, sehingga siswa masih dituntun dalam membuat pertanyaan, (2)siswa kurang bekerja sama dalam diskusi kelompok, masih saja ada siswa yang bercanda saat membuat sebuah pertanyaan, (3) hasil diskusi kelompok hanya dikerjakan oleh satu atau dua orang siswa yang pintar, (4) Metode problem solving masih baru untuk di SD No. 2 Dalung sehingga siswa harus dituntun dengan pelan-pelan agar siswa lebih memahami pembelajaran, (6) siswa yang malas belajar, bersikap acuh tak acuh dan tidak mau membaca serta mendengarkan hasil temuan temannya di kelompok lain.

Berdasarkan kendala-kendala yang menyebabkan belum tercapainya peningkatan hasil belajar siswa, maka diadakan penyempurnaan pada siklus berikutnya yaitu: (1) mengarahkan siswa membuat suatu pertanyaan dengan mengunakan kata kunci seperti kata "Apa, kenapa, mengapa”. Sehinga siswa lebih mudah membuat peertanyaan dari suatu permasalahan, (2) merancang Metode Problem Solving dengan menarik sehingga model ini tidak telihat kaku bagi siswa namun bisa membuat siswa seolah-olah bermain sambil belajar, (3) mengingatkan siswa agar serius melaksanakan kegiatan pembelajaran karena diakhir kegiatan pembelajaran akan diberikan tes ulangan, (4) guru memberikan pertanyaan kepada siswa untuk mengetahui keseriusan siswa dalam melaksanakan tugas, (5) memberikan penghargaan pada siswa yang aktif dalam diskusi kelompok, (6) memberikan penghargaan pada kelompok yang aktif dalam mengikuti kegiatan pembelajaran.

Hasil refleksi yang diperoleh pada siklus I selanjutnya dijadikan acuan dalam melakukan perbaikan pembelajaran yang akan dilakukan pada siklus II. Sehingga dapat dikatakan pelajaran IPA pada siklus I belum tuntas jadi perlu diadakan refleksi dalam menentukan perbaikan pembelajaran dengan melanjutkan ke siklus II.

Berdasarkan hasil pengumpulan data hasil belajar dan analisis yang dilakukan pada siklus I maka secara klasikal penelitian pada siklus II sudah berhasil karena sudah memenuhi kriteria keberhasilan penelitian yaitu penelitian dikatakan berhasil bila nilai rata-rata kelas minimal 80. Sedangkan nilai ratarata kelas yang diperoleh sudah melebihi nilai rata-rata kelas yaitu 82,58 berada pada rentang $80 \%-89 \%$ dengan kriteria tinggi.

Hasil yang diperoleh pada siklus I dan siklus II dapat diketahui bahwa persentase rata-rata pada siklus I sebesar 72,12\%, dan pada siklus II juga mengalami peningkatan menjadi 82,58\%. Peningkatan persentase rata-rata dari siklus I ke siklus II meningkat sebesar 10,45\%. Berdasarkan hasil penelitian yang telah dilaksanakan selama dua siklus, menunjukkan adanya peningkatan hasil belajar siswa dengan penerapan metode Problem Solving di kelas VA SD No. 2 Dalung tahun pelajaran 2016/2017.

Berdasarkan hasil analisis data pada siklus II maka diperoleh rata-rata hasil belajar siswa mencapai 82,58 dan persentase nilai rata-rata siswa sudah mencapai 82,58\% berada dalam kategori "tinggi". Untuk lebih jelasnya, peningkatan hasil belajar IPA siswa kelas V semester ganjil SD No. 2 Dalung Tahun Pelajaran 2016/2017 pada siklus I dan siklus II dapat dilihat pada Tabel 2. 
Tabel 2. Rekapitulasi Data Hasil PTK Siklus I dan Siklus II

\begin{tabular}{cccrc}
\hline $\begin{array}{c}\text { Aspek yang } \\
\text { Diteliti }\end{array}$ & TINDAKAN & $\begin{array}{c}\text { PAP } \\
(\%)\end{array}$ & PERSENTASE & KATEGORI \\
\hline Hasil Belajar & PraSiklus & $55-64$ & $64,09 \%$ & Rendah \\
\cline { 2 - 5 } IPA & Siklus I & $65-79$ & $72,12 \%$ & Sedang \\
\cline { 2 - 5 } & Siklus II & $80-89$ & $82,58 \%$ & Tinggi \\
\hline
\end{tabular}

Berdasarkan Tabel 2 dapat diketahui bahwa persentase rata-rata pada pra-siklus sebesar 64,09\%, siklus I sebesar 72,12\%, dan pada siklus II juga mengalami peningkatan menjadi 82,58\%. Peningkatan persentase rata-rata dari siklus I ke siklus II meningkat sebesar 10,45\%. Secara lengkap peningkatan hasil belajar IPA prasiklus, siklus I, dan siklus II di atas dapat disajikan seperti pada Gambar 1.

Gambar 1 Diagram Batang Peningkatan Hasil Belajar IPA Kelas VA SD No. 2 Dalung

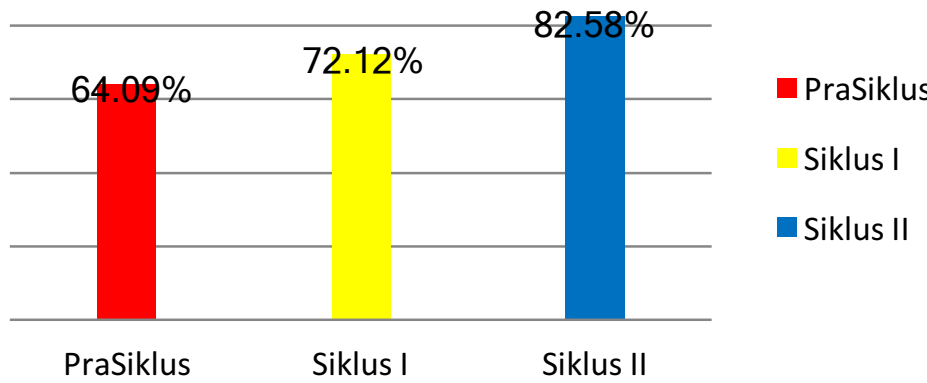

Dari analisis data pada siklus I dan siklus II di atas, diketahui bahwa hasil belajar IPA meningkat melalui metode problem solving pada siswa kelas VA SD No. 2 Dalung semester ganjil tahun pelajaran 2016/2017. Hal ini dapat dilihat dari rata-rata hasil belajar siswa secara klasikal pada siklus I sebesar 72,12 dengan persentase rata-rata $72,12 \%$ yang tergolong pada kategori rendah. Pada siklus II rata-rata meningkat menjadi 82,58 dengan persentase rata-rata sebesar 82,58\% yang berada dalam kategori tinggi dengan peningkatan rata-rata hasil belajar siswa.

Hasil yang diperoleh dalam penelitian ini di dukung oleh penelitian sejenis dengan menggunakan metode problem solving yang dilakukan oleh beberapa peniliti. Hasil penelitian yang hampir sama diperoleh oleh Handayani, (2009) yaitu Penerapan Model Pembelajaran Berbasis Masalah (Problem Based Learning) dan Pembelajaran Kooperatif (Cooperative Learning) Tipe Jig Saw Untuk Meningkatkan Aktivitas Belajar, Hasil Belajar dan Respon Belajar Siswa. Penerapan Pendekatan Problem Solving dalam Meningkatkan Kemampuan Berfikir Kritis Peserta didik (Jamhari, 2010). Problem Solving dapat meningkatkan keterampilan berpikir analitis siswa (Ikhwanudin, 2010).

\section{Simpulan dan Saran}

Peningkatan persentase rata-rata dari siklus I ke siklus II sebesar 10,45\%. Terjadinya peningkatan hasil belajar siswa kelas VA semester ganjil pada mata pelajaran IPA disebabkan oleh pada pelaksanaan tindakan siklus II tidak lagi muncul kendala-kendala seperti pada siklus I seperti siswa sudah mulai antusias mengerjakan tugas dan berdiskusi dengan kelompoknya sehingga penguasaan materi siswa mulai ada peningkatan dan siswa sudah terbiasa dengan penerapan metode problem solving yang telah diterapkan oleh guru, semua siswa terlibat secara aktif dalam pembelajaran. Pada siklus II, dalam proses pembelajaran siswa sudah terbiasa dan telah terlatih belajar dengan mengikuti penerapan metode problem solving. Dalam proses pembelajaran siswa sudah terbiasa dan telah terlatih belajar dengan mengikuti penerapan metode problem solving. Hal ini terlihat dari kegiatan yang dilakukan siswa yaitu siswa sudah terlibat aktif dalam proses pembelajaran, siswa sudah antusias dalam mengikuti pembelajaran yang dilaksanakan, sudah saling membantu antar anggota kelompok, serius dalam diskusi kelompok, berani mengajukan pertanyaan dan menyampaikan argumentasinya. Metode problem solving memberikan kesempatan kepada siswa untuk bekerjasama dengan teman kelompoknya, berinteraksi sosial, dan membagikan ide-ide baru dalam kelompok bisa dikatakan seperti tutor sebaya, dimana seorang siswa memberitahukan temannya yang belum paham atau kurang mampu dalam menerima pelajaran. 
Dari uraian di atas, secara umum telah mampu menjawab rumusan masalah. Penelitian ini dapat dikatakan berhasil, karena semua kriteria yang ditetapkan telah terpenuhi. Jadi, dapat dinyatakan bahwa penerapan metode problem solving dapat meningkatkan hasil belajar IPA siswa kelas VA SD No. 2 Dalung tahun pelajaran 2016/2017.

\section{Daftar Pustaka}

Agus Suarimbawa, Kadek., AAIN Marhaeni, GAP Suprianti. (2017). An Analysis of Authentic Assessment Implementation Based on Curriculum 2013 in SMP Negeri 4 Singaraja. Journal of Education Research and Evaluation. Vol. 1 No.1.

A Firli, R Rismayani, PMT Sitorus, B Manuel. (2017). Implementing Mixed Method of Peer Teaching and Problem Solving on Undergraduate Students. Journal of Education Research and Evaluation. Vol. 1 No.1.

Agung, A.A. Gede. (2010). Metodologi Penelitian Pendidikan. Singaraja: Undiksha Singaraja.

Angga Wiguna, Sang Gede., I Wayan Widiana, Dewa Nyoman Sudana. Penerapan Pembelajaran Berbasis Otak Untuk Meningkatkan Kemampuan Pemecahan Masalah Matematika Siswa Kelas V Sekolah Dasar. Mimbar PGSD. Vol 5 No 2 Tahun 2016.

Anggi Pratiwi, Ni Luh Putu., Ni Wayan Arini, I Wayan Widiana. (2014). pengaruh Model Pembelajaran Problem Solving Dan Reasoning Berbasis Brainstorming Terhadap Kemampuan Berpikir Kreatif Pada Mata Pelajaran IPA Bagi Siswa Kelas V di Gugus I Kecamatan Tejakula, Kabupaten Buleleng. Mimbar PGSD. Vol. 2 No 1.

Bahri, Syaiful, dkk. (2010). Strategi Belajar Mengajar. Jakarta: Rineka Cipta.150

Dharma, Surya. (2008). Strategi pembelajaran dan pemilihannya. Jakarta: direktorat tenaga kependidikan Departemen Pendidikan Nasional.

Djajadisastra, Jusuf. (1982). Metode-Metode Mengajar. Bandung: Angkasa.

Firli, A., Rismayani, F., P.M.T. Sitorus, B. Manuel (2017). Implementing Mixed Method Of Peer Teaching And Problem Solving On Undergraduate Students. Journal of Education Research and Evaluation. Vol.1 (1) pp. 1-5.

Gulo, W. (2002). Metode Penelitian. Jakarta: PT. Grasindo.

Handayani, Sri. (2009). Penerapan Model Pembelajaran Berbasis Masalah (Problem Based Learning) dan Pembelajaran Kooperatif (Cooperative Learning) Tipe Jig Saw Untuk Meningkatkan Aktivitas Belajar, Hasil Belajar dan Respon Belajar Siswa pada Mata Pelajaran Ekonomi di SMA Negeri 2 Malang. Jurnal Pendidikan Pendidikan Ekonomi, Volume 2, Halaman 38-52

Ikhwanudin. (2010). Problem Solving dalam Pembelajaran Fisika untuk Meningkatkan Keterampilan Mahasiswa Berpikir Analitis. Jurnal Kependidikan, 40 (2), 2010: 216 \& 261.

Istri Utami, Ida Ayu Made. (2017). The Study of Potentials and Problems in Reading Faced By the Eighth Grade Students of Junior High School. Journal of Education Research and Evaluation. Vol. 1 No.1.

Jamhari. (2010). Penerapan Pendekatan Problem Solving dalam Meningkatkan Kemampuan Berfikir Kritis Peserta didik SMP Negeri 21 Palu pada Mata Pelajaran Biologi. Jurnal Biodidaktis, 3 (2), 2010: 84.

Janet E. Davinson dan Robert J.S, (2003). Problem Solving, UK: Cambridge University, 2003; p. 3-4

Ni Wayan Juniati, I Wayan Widiana. (2017). Penerapan Model Pembelajaran Inkuiri Untuk Meningkatkan Hasil Belajar IPA. Jurnal Ilmiah Sekolah Dasar. Vol. 1 No. 1.

Kartawidjaya, Omi. (1988). Metode Mengajar Geografi. Jakarta: Depdikbud.

Kasihani, Kasbolah dan Sukarnyana I Wayan. (2006). Penelitian Tindakan Kelas (PTK ). Malang: Universitas Negeri Malang.

Nastitie Ariawan, Vina Anggia., Inne Marthyanne Pratiwi. (2017). Eksplorasi Kemampuan Siswa Kelas IV Sekolah Dasar dalam Penyelesaian Soal Cerita Matematika. Jurnal Pendidikan Indonesia. Vol. 6 No. 1. 
Nurliawaty, Lilis., Mujasam., Irfan Yusuf \& Sri Wahyu Widyaningsih. (2017). Lembar kerja peserta didik (LKPD) Berbasis problem solving polya. Jurnal Pendidikan Indonesia. Vol. 6, No.1, pp: 72-81

Parwati, NN. (2015). Pengembangan Model Pembelajaran Pemecahan Masalah Berorientasi Kearifan Lokal Pada Siswa SMP di Kota Singaraja. Jurnal Pendidikan Indonesia. Vol. 4 No. 2.

Prawindaswari, Putu Dian., I Made Suarjana, I Wayan Widiana. (2015). Pengaruh Model Pembelajaran Search, Solve, Create, And Share (SSCS) Terhadap Hasil Belajar IPA Siswa Kelas IV SD Gugus VI Kecamatan Sukasada Kabupaten Buleleng Tahun Ajaran 2014/2015. Mimbar PGSD. Vol. 3. No. 1.

Peri Artawan, Eka., I Gusti Ngurah Japa, I Wayan Widiana. (2014). Pengaruh Model Pembelajaran SSCS Terhadap Kemampuan Pemecahan Masalah Matematika. Mimbar PGSD. Vol. 2 No 1.

Rusman. (2011). Model - Model Pembelajaran dan Mengembangkan Profesionalisme Guru. Jakarta: Raja Grafindo Persada.

Sanjaya, I Made Agus. (2008). Perbedaan Penerapan Metode Penemuan dan Metode Diskusi Terhadap Hasil Belajar Matematika Siswa SMP Terbuka.Skripsi (tidak diterbitkan). Singaraja: Undiksha

Sri Udayanti, IAG., Putu Nanci Riastini. (2017). Penerapan Metode Take And Give Untuk Meningkatkan Hasil Belajar IPA Siswa Kelas IVa. Jurnal Ilmiah Sekolah Dasar. Vol. 1 No. 1.

Sudjana, Nana. (1987). Dasar-Dasar Proses Belajar Mengajar.Bandung: Sinar Baru Algensindo

Sudjana, Nana dan Ahmad Rivai. (1991). Media Pengajaran. Bandung: CV. Sinar Baru.

Sudana, I P. Ari., I Gede Astra Wesnawa. (2017). Penerapan Model Pembelajaran Kooperatif Tipe STAD Untuk Meningkatkan Hasil Belajar IPA. Jurnal Ilmiah Sekolah Dasar. Vol.1 (1) pp. 1-8.

Surjani, W. (2010). Dasar-dasar Sains. Jakarta: Indeks; , p.13-14

Syaiful Bahri dan ahmd Zain, (2006). Strategi Belajar Mengajar. Jakarta: Rineka Cipta; p .92

Theresia Kristianty, (2010). Evaluasi Pembelajaran Bagi Mahasiswa PAUD dan DIKDAS, Jakarta: UNJ, 2010; p.161

Utomo Danajaya, (2010). Media Pembelajaran Aktif. Bandung: Nuansa; p.131

Wardhani, I GAK, dkk. (2007). Penelitian Tindakan Kelas (PTK). Jakarta: Universitas Terbuka.

Widiana, I Wayan. (2016). Pengembangan Asesmen Proyek Dalam Pembelajaran IPA di Sekolah Dasar. Jurnal Pendidikan Indonesia Vol 6. No 2 tahun 2016.

Widiana, I Wayan. (2016). E-Modul Berorientasi Pemecahan Masalah Dalam Pembelajaran Statistik Inferensial. Prosiding Semnas Hasil (http://jurnal.unmas.ac.id/index.php/pros/article/view/340)

Widiana, I Wayan., I Nyoman Jampel. (2016). Learning Model and Form of Assesment toward the Inferensial Statistical Achievement By Controlling Numeric Thingking Skills. International Journal of Evaluation and Research in Education (IJERE). Vol. 5 No. 2.

Yamin, Martinis. (2013). Strategi dan Metode dalam Model Inovasi Pembelajaran. Jakarta: Gaung Persada Press group 